\title{
A construção jurisprudencial acerca do controle judicial sobre o plano de recuperação judicial
}

\section{The jurisprudence construction about the judicial control of the judicial reorganization plan}

\author{
Alexandre Ferreira de Assumpção Alves* \\ Matheus Bastos Azevedo de Oliveira**
}

\section{RESUMO}

Estuda-se o plano de recuperação judicial, instituto agregado de grande margem ao exercício da autonomia de vontade, à luz da decisão de concessão da recuperação judicial e homologação do plano de recuperação judicial. A Lei $n^{\circ} 11.101$, de 9 de fevereiro de 2005, conferiu ao credor, devedor e juiz papéis determinantes na reestruturação da atividade econômica em crise. Não obstante, após 10 anos de aplicação da lei, muitas lacunas são apontadas pela doutrina e tribunais diante da sofisticação dos casos apreciados à luz da lei falimentar, demandando, por vezes, extensa atividade interpretativa ao operador da lei. O controle judicial realizado sobre o conteúdo plano de recuperação judicial, elaborado por devedor e credor, requer acurada destreza do julgador para não substituir o papel dos agentes privados no procedimento de recuperação judicial. Nesse sentido, o estudo do entendimento dos tribunais em torno de destacadas questões revela-se essencial à compreensão e desenvolvimento dos institutos legais, buscando-se enxergar a construção jurisprudencial em torno da matéria.

Palavras-chave: Recuperação judicial. Plano de recuperação judicial. Assembleia Geral de Credores. Lei n 11.101/2005.

Doutor em Direito pela Universidade do Estado do Rio de Janeiro. Professor Associado de Direito Empresarial nas Faculdades de Direito da UERJ e da UFRJ. Docente permanente do PPDG da UERJ, linha de pesquisa Empresa e Atividades Econômicas. Líder do Grupo de Pesquisa Empresa e Atividades Econômicas do CNPq. Rio de Janeiro - RJ - Brasil. Email: asaa@uol.com. br

* Graduado pela Universidade Federal do Rio de Janeiro. Rio de Janeiro - RJ - Brasil. Email: mboliveira@demarest.com.br 


\section{ABSTRACT}

The study goes through the judicial reorganization plan exploring its private interest by the decision that grants the judicial reorganization and homologates the judicial reorganization plan. The Law n. 11,101, of February 9, 2005, has given the creditor, debtor and judge decisive roles in the restructuring of economic activity in crisis. Nevertheless, after 10 years of law effectiveness, many gaps are identified by the doctrine and Courts whereas the sophistication of the cases examined under the brazilian's bankruptcy law, demanding sometimes extensive interpretation by the operator of the law. The judicial review carried out on the judicial reorganization plan content, prepared by debtor and creditor, requires accurate dexterity of the judge for not replacing the role of private actors in the judicial recovery procedure. In this sense, the study of understanding issues of the Courts is essential to the understanding and development of legal institutions, seeking to analysis the jurisprudence construction around the matter.

Keywords: Judicial recovery. Judicial reorganization plan. Creditors' meeting. Law $n^{\circ} 11.101 / 2005$.

\section{Introdução}

A Lei n 11.101/2005 (“LFRE”) inovou ao trazer para o cenário jurídico nacional o regime da recuperação judicial e introduzir significativas mudanças ao procedimento judicial destinado à manutenção da atividade empresarial em crise, anteriormente regulado pelo rígido e estreito regime de concordata preventiva, previsto no Decreto-Lei $n^{\circ}$ 7.661/1945. Em franco contraste ao Decreto-Lei ab-rogado, a lei vigente compreende a flexibilização, em parte, das condições para a concessão da recuperação como caminho ao atendimento de seus princípios basilares, franqueando certa autonomia negocial ao devedor e seus credores para o desenvolvimento de um plano de recuperação judicial destinado a reerguer a atividade econômica em apuros.

Não obstante, se por um lado a autonomia conferida às partes Ihes assegura papel fundamental na negociação do conteúdo do plano de recuperação, por outro a submissão do ato à homologação judicial para a efetiva concessão da recuperação judicial conduz a um 
questionamento: estaria o juiz vinculado ao acordo de vontades entre o devedor e seus credores?

A indagação compreende duas possíveis formas de controle judicial: (i) sobre as deliberações da Assembleia Geral de Credores; e (ii) sobre o conteúdo do plano de recuperação judicial. Para os fins deste estudo, será observado o do grau de controle judicial exercido sobre o conteúdo do plano de recuperação judicial.

Após dez anos de vigência da LFRE, verificam-se lacunas no ordenamento que demandam a atuação judicial para a interpretação e compreensão de seus institutos. Nesse cenário, a jurisprudência assume função de destaque para o preenchimento dessas lacunas e fixação de entendimentos que visem atribuir segurança jurídica a uma legislação estratégica à economia nacional. A sua análise, por conseguinte, revelase imperiosa às reflexões em torno da matéria.

Com a utilização do método dedutivo-analítico e de pesquisa bibliográfica e documental, serão evidenciados casos empíricos nos quais restou configurada a existência de controle judicial ao plano de recuperação judicial nos tribunais brasileiros. Sem embargo, antes de adentrar propriamente no estudo do conteúdo plano e seus requisitos, cumpre analisar o instituto da Assembleia Geral de Credores, figura sui generis voltada à deliberação do plano de recuperação judicial através da vontade coletiva dos credores, definitiva ao sucesso do procedimento.

\section{A Assembleia Geral de Credores}

Define-se a Assembleia Geral de Credores, primordialmente, em torno de suas principais características: (i) reunião colegiada de credores, convocada e instalada de acordo com as prescrições legais; (ii) com intuito deliberativo, isto é, decisório; (iii) sobre matérias previstas ou não defesas em lei ${ }^{1}$. Naturalmente, a partir dessas características,

A definição proposta sintetiza as definições elaboradas pelos autores Jairo Saddi (2006, p. 27), Sérgio Campinho (2012, p. 77) e Fábio Ulhôa Coelho (2013). 
sublevam-se importantes desdobramentos e estudos doutrinários, ora compartilhados, ora conflitantes. Dentre as diversas matérias de sua competência, a assembleia será analisada quando convocada para deliberar acerca do plano de recuperação judicial, atribuição que lhe é conferida no art. 35, I, a, da LFRE.

\subsection{A Assembleia Geral de Credores e a deliberação sobre o plano de recuperação judicial}

A Assembleia Geral de Credores, destinada a aprovar, rejeitar ou modificar o plano de recuperação judicial proposto pelo devedor, pode ser considerada como clímax do procedimento de recuperação judicial, já que o seu resultado é capaz de direcionar o devedor a caminhos diametralmente opostos: a reestruturação ou a falência.

Entretanto, embora se revele medular ao procedimento, a assembleia não é órgão obrigatório à deliberação do plano. Desde a apresentação deste em juízo, a qualquer credor é conferida a oportunidade de se opor ao seu conteúdo, por meio de objeções, no prazo de 30 dias, na forma do art. 55 da LFRE $^{2}$. Caso não seja apresentada nenhuma objeção ao plano nesse prazo, dever-se-á considerá-lo tacitamente aprovado, na forma do art. 57 da LFRE. No entanto, uma vez formulada objeção por qualquer dos credores, será sempre obrigatória ${ }^{3}$ a convocação do conclave pelo juiz, nos termos do artigo art. 56 da LFRE 4 .

2 "Art. 55. Qualquer credor poderá manifestar ao juiz sua objeção ao plano de recuperação judicial no prazo de 30 (trinta) dias contado da publicação da relação de credores de que trata o § 20 do art. $7^{\circ}$ desta Lei. Parágrafo único. Caso, na data da publicação da relação de que trata o caput deste artigo, não tenha sido publicado o aviso previsto no art. 53, parágrafo único, desta Lei, contar-se-á da publicação deste o prazo para as objeções."

3 Nesse sentido, SÃO PAULO. Tribunal de Justiça. Agravo de Instrumento n. 005.45.5824400. Rel. Manoel de Queiroz Pereira Calças, j. 26/03/2008.

4 No procedimento de concordata preventiva, o credor estava municiado dos "embargos à concordata", pelo qual poderia se opor à concessão do regime ao devedor perante o juiz, conforme os artigos 142 e 143 do Decreto-lei n. 7.661/1945. Diferentemente dos embargos, a objeção ao plano não será apreciada pelo Juízo, destinando-se à suscitar a convocação de assembleia geral de credores para deliberação da matéria no conclave. Nesse sentido, o seguinte trecho do acórdão proferido no julgamento do Agravo de Instrumento n. 0047459-81.2009.9.19.0000, pela Décima Quinta Câmara Cível do Estado do Rio de Janeiro, sob relatoria do Des. Sergio Lucio Cruz, em 26/01/2010: "Não competia ao juiz, portanto, na decisão que homologou o "Plano", examinar as objeções apresentadas, por ser isso matéria de exclusiva competência da assembleia geral." 
O quorum de instalação da assembleia, em $1^{\text {a }}$ convocação, está estampado no art. $37, \S 2^{\circ}$, da $\operatorname{LFRE}^{5}$ e requer a presença de mais da metade dos créditos de cada uma das quatro classes de credores previstas no art. $41^{6}$, quando existentes, computados pelo valor. Ausente o quorum mínimo, será observada a data designada no edital de convocação para a sua realização em $2^{a}$ convocação, a qual será instalada independentemente da apuração do quorum, observado o prazo mínimo de cinco dias.

Instalada a assembleia de credores, terá início a deliberação e subsequente votação do plano de recuperação judicial, que se dará de forma segregada para cada classe do art. 41.

A rigor, para ser aprovado em assembleia, o plano de recuperação judicial depende do consentimento de todas as classes de credores, na forma delineada nos artigos 41 e 45 da LFRE. Não obstante, em apreço ao princípio da preservação da empresa e aos objetivos da recuperação delineados no art. $47^{7}$, o art. $58, \S 1^{08}$, prevê a possibilidade

5 "Art. 37. A assembléia será presidida pelo administrador judicial, que designará 1 (um) secretário dentre os credores presentes. $\S 2^{\circ} \mathrm{A}$ assembléia instalar-se-á, em $1 \mathrm{a}$ (primeira) convocação, com a presença de credores titulares de mais da metade dos créditos de cada classe, computados pelo valor, e, em 2a (segunda) convocação, com qualquer número".

$6 \quad$ "Art. 41. A assembléia-geral será composta pelas seguintes classes de credores: I - titulares de créditos derivados da legislação do trabalho ou decorrentes de acidentes de trabalho; II titulares de créditos com garantia real; III - titulares de créditos quirografários, com privilégio especial, com privilégio geral ou subordinados. IV - titulares de créditos enquadrados como microempresa ou empresa de pequeno porte."

7 "Art. 47. A recuperação judicial tem por objetivo viabilizar a superação da situação de crise econômico-financeira do devedor, a fim de permitir a manutenção da fonte produtora, do emprego dos trabalhadores e dos interesses dos credores, promovendo, assim, a preservação da empresa, sua função social e o estímulo à atividade econômica".

8 "Art. 58. Cumpridas as exigências desta Lei, o juiz concederá a recuperação judicial do devedor cujo plano não tenha sofrido objeção de credor nos termos do art. 55 desta Lei ou tenha sido aprovado pela assembléia-geral de credores na forma do art. 45 desta Lei. $\S 1^{\circ} \mathrm{O}$ juiz poderá conceder a recuperação judicial com base em plano que não obteve aprovação na forma do art. 45 desta Lei, desde que, na mesma assembléia, tenha obtido, de forma cumulativa:

I - o voto favorável de credores que representem mais da metade do valor de todos os créditos presentes à assembléia, independentemente de classes; II - a aprovação de 2 (duas) das classes de credores nos termos do art. 45 desta Lei ou, caso haja somente 2 (duas) classes com credores votantes, a aprovação de pelo menos 1 (uma) delas;

III - na classe que o houver rejeitado, o voto favorável de mais de 1/3 (um terço) dos credores, computados na forma dos $\S \S 1^{\circ}$ e $2^{\circ}$ do art. 45 desta Lei. $\quad \S 2^{\circ} \mathrm{A}$ recuperação judicial somente poderá ser concedida com base no $\S 1^{\circ}$ deste artigo se o plano não implicar tratamento diferenciado entre os credores da classe que o houver rejeitado". 
de concessão da benesse e homologação do plano que tenha alcançado, cumulativamente, os requisitos elencados nos incisos do referido parágrafo $1^{\circ}$. Visou a lei, com isso, inibir o credor que, por gozar de posição majoritária em uma determinada classe pelo valor de seu crédito, pudesse decidir sozinho pela aprovação ou rejeição do plano de recuperação judicial.

Após a votação do plano na assembleia, seu resultado será submetido à apreciação judicial, devendo o juiz adotar a solução prevista no art. 56, $\S 4^{\circ}$ da $\operatorname{LFRE}^{9}$ em caso de rejeição, ou no art. 58 em caso de aprovação.

\section{O instrumento jurídico da recuperação judicial: o plano de recuperação}

Previsto na seção III, capítulo III, da LFRE, o plano de recuperação judicial é o instrumento jurídico obrigatório e indispensável para que o devedor possa pleitear a concessão de sua recuperação judicial. Tratase de uma proposta, tempestivamente oferecida, exclusivamente pelo devedor em recuperação judicial, direcionada a seus credores titulares de obrigações existentes à data do pedido, ainda que vincendas. No documento, o devedor arrola os meios pelos quais pretende superar a crise econômico-financeira ou se prevenir de uma crise iminente, franqueando a manutenção da sua atividade empresarial e o pagamento dos seus débitos. Embora o art. 50 da LFRE disponha variadas formas de o devedor estruturar sua recuperação, pode o plano tratar incontáveis meios de reestruturação, devendo encontrar o ponto de convergência entre o devedor e seus credores para alcançar a sua aprovação (CAMPINHO, 2012, p. 165).

Entretanto, ainda que se revele um ato eminentemente privado e de mais flexível conteúdo, nem toda a liberdade é concedida aos agentes

9 "Art. 56. Havendo objeção de qualquer credor ao plano de recuperação judicial, o juiz convocará a assembleia geral de credores para deliberar sobre o plano de recuperação. [...] § $4^{\circ}$ Rejeitado o plano de recuperação pela assembleia geral de credores, o juiz decretará a falência do devedor." 
na negociação das cláusulas do plano. Diversas são as limitações legais e principiológicas voltadas a lhe conferir validade e eficácia, de modo a salvaguardar interesses individuais e coletivos dos envolvidos no processo, coibindo-se sua utilização como manto à prática de fraudes e conluios entre devedor e certos credores.

\subsection{Requisitos de admissibilidade do plano de recuperação judicial}

$\mathrm{O}$ art. 53 da $\operatorname{LFRE}^{10}$, além de estabelecer que compete ao devedor apresentar em juízo o plano de recuperação, arrola, ainda, quatro elementos essenciais e que merecem rigorosa observância: (i) a tempestividade; (ii) a discriminação pormenorizada dos meios de recuperação a serem empregados; (iii) a demonstração da sua viabilidade econômica; e, por fim, (iv) a apresentação de laudos econômicofinanceiros e de avaliação de ativos, elaborados por profissional ou sociedade especializada.

Primeiramente, deve o plano ser apresentado no prazo improrrogável de 60 dias, a contar da publicação do edital de deferimento da recuperação judicial, conforme o art. 52, $\$ 1^{\circ}$, da LFRE ${ }^{11}$ (UBALDO, 2008, p. 96).

Apresentado tempestivamente, o plano deve indicar, de forma clara e detalhada, os meios pelos quais o devedor pretende se reestruturar,

10 "Art. 53. O plano de recuperação será apresentado pelo devedor em juízo no prazo improrrogável de 60 (sessenta) dias da publicação da decisão que deferir o processamento da recuperação judicial, sob pena de convolação em falência, e deverá conter: I - discriminação pormenorizada dos meios de recuperação a ser empregados, conforme o art. 50 desta Lei, e seu resumo; II demonstração de sua viabilidade econômica; e III - laudo econômico-financeiro e de avaliação dos bens e ativos do devedor, subscrito por profissional legalmente habilitado ou empresa especializada.

Parágrafo único. O juiz ordenará a publicação de edital contendo aviso aos credores sobre o recebimento do plano de recuperação e fixando o prazo para a manifestação de eventuais objeções, observado o art. 55 desta Lei."

11 Cabe, outrossim, ressaltar que o legislador não considerou a ocorrência de razões de força maior que justificariam a entrega intempestiva do plano. Tampouco a lei deu ao juiz ou assembleia de credores a faculdade de examinar tais justificativas, pois determinou a decretação de falência ex officio na hipótese de apresentação extemporânea do plano. 
além da possibilidade de consegui-lo uma vez empregados os meios previstos. (PACHECO, 2007, p. 154).

A recuperação judicial destina-se aos empresários individuais e sociedades empresárias em dificuldade (art. $1^{\circ}$ da LFRE), mas capazes evidenciar meios viáveis de soerguimento de sua atividade econômica e justificar os sacrifícios impostos aos seus credores. Não se deve tolerar a sua utilização como ferramenta para postergar a decretação de falência de atividades manifestamente insolventes, ou, tão menos, propiciar o esvaziamento patrimonial sob a chancela judicial. É elementar, portanto, que o devedor aponte, no plano de recuperação judicial, a capacidade de reestruturar-se, sob pena de atestar a sua real insolvência, hipótese na qual deveria confessar sua falência, nos termos do art. 105 da LFRE. Assim se posiciona Márcio Luiz Aguiar (2006, p. 118) sobre o tema:

[...] o plano, como já dito, deve apresentar claramente a situação da empresa, detectar suas inconsistências gerenciais, acusar os equívocos que acarretam a crise econômico-financeira e até mesmo jurídicas das atividades a serem desenvolvidas. Esses recursos de análise do ambiente empresarial objetivam prever a superação da crise e embasar a lógica e mercadologicamente as ações planejadas, justificando também os caminhos escolhidos. Enfim, o plano de recuperação ao qual se subordinará o processo de recuperação deve apresentar coerência, veracidade e qualidade, posto que o erro neste estágio, até mesmo por definição legal (art. $56, \S 4^{\circ}$, da Lei $\mathrm{n}$. 11.101/2005), acarreta a falência.

Finalmente, deve-se destacar que, ao se sustentar a apreciação do requisito contido no art. 53, II, não se pretende que o juiz aufira a viabilidade material do plano de recuperação judicial ou intervenha no seu conteúdo. À exceção de raros posicionamentos contrários ${ }^{12}$,

12 RIO GRANDE DO SUL. Tribunal de Justiça. Quinta Câmara Cível. Agravo de Instrumento n. 70043342070. Rel. Des. Jorge Luiz Lopes do Canto, Julgado em 31/08/2011; e RIO GRANDE DO SUL. Tribunal de Justiça. Quinta Câmara Cível. Agravo de Instrumento n 70035509736. Rel. Des. Jorge Luiz Lopes do Canto, j. 24/11/2010. 
é incontroverso que a valoração da viabilidade econômico-financeira do devedor é matéria de competência exclusiva da Assembleia Geral de Credores - caso haja objeção -, não podendo o juiz se sobrepor à decisão assemblear que a julgue possível ou não ${ }^{13}$. O papel jurisdicional limitar-se-á à verificação se o devedor apresenta prova documental da viabilidade do seu plano, ainda que de forma abstrata, no laudo econômico-financeiro. Pertinente, pois, que o juiz verifique a inexistência de sua indicação ${ }^{14}$, resguardando-se a exclusiva competência da assembleia para avaliar e, posteriormente, aprovar ou rejeitar o plano.

O entendimento, inclusive, está concretizado no enunciado n. 46, aprovado em 2012 na I Jornada de Direito Comercial: "Não compete ao juiz deixar de conceder a recuperação judicial ou de homologar a extrajudicial com fundamento na análise econômico-financeira do plano de recuperação aprovado pelos credores."15.

Como últimos requisitos contidos no art. 53 da LFRE, os laudos econômico-financeiros e de avaliação de ativos destinam-se a certificar a momentânea situação patrimonial do devedor e abrangem critérios determinantes à analise dos credores, tais como: valor atualizado dos ativos integrantes do seu patrimônio (v.g. móveis, imóveis, marcas, patentes e

13 SÃO PAULO. Tribunal de Justiça. Câmara Reservada à Falência e Recuperação. Agravo de Instrumento n. 994.09.319061-0, j. 06/04/2010, destacando-se que: "Por fim, em relação à inviabilidade do plano, tem-se que é matéria de exclusivo exame por parte dos credores, que o aceitaram, escapando ao Poder Judiciário deliberação em sentido contrário. Destinatário do plano de recuperação são os credores. Não há previsão normativa de atuação jurisdicional com a finalidade de julgar o plano de recuperação. A menos que alguma previsão do plano venha a incidir em ofensa a norma de ordem pública, em alguma espécie de inconstitucionalidade ou, enfim, em algum tipo de abuso, o Poder Judiciário não examina o plano de recuperação e sua viabilidade."

14 RIO GRANDE DO SUL. Tribunal de Justiça, Sexta Câmara Cível. Agravo de Instrumento n. 70037009958, rel. Des. Luís Augusto Coelho Braga, j. 9/9/2010. Sustentou a Turma Julgadora que: "Compulsando-se os presentes autos (fl. 534/544), infere-se não terem sido apresentados os laudos mencionados no inciso III, do dispositivo acima transcrito, cuja falta ensejou a realização de laudo pericial já referido, pelo qual se observou a ausência do requisito contido no inciso II; viabilidade econômica. Logo, o Magistrado a quo atuou com respaldo da legislação incidente à espécie, segundo a qual, uma vez desatendido o prazo para a apresentação do plano de recuperação com as respectivas especificações, será decretada a falência.".

15 JORNADA DE DIREITO COMERCIAL I., 23-24 de outubro de 2012. Brasília: Conselho da Justiça Federal, Centro de Estudos Judiciários, 2013. 
outros intangíveis), fluxo de caixa, receitas, despesas etc. Diferentemente do ensaio sobre a viabilidade econômica do plano, os laudos econômicofinanceiros e de avaliação de ativos são necessariamente formulados e subscritos por contador ou sociedade especializada, assegurando-se maior transparência e confiança aos credores acerca da real situação patrimonial do devedor (TOMAZETTE, 2014, p. 192).

2.20 recebimento do plano e a apreciação dos requisitos elencados no art. 53

Conforme exposto, os requisitos de admissibilidade do plano, afetos à sua própria existência (TOMAZETTE, 2014, p. 192), destinam-se a propiciar informações substanciais para que seja objeto de deliberação em assembleia, caso haja necessidade. Confira-se o entendimento de Luiz Roberto Ayoub e Cássio Cavalli (2013, p. 218):

Esses três elementos contidos no plano de recuperação judicial permitem que se reduza assimetria de informações entre a empresa devedora e os seus credores, de modo a que os credores possam deliberar pela aprovação, modificação ou rejeição do plano. Com efeito, conhecidos os meios de recuperação judicial apresentados, os credores terão condições de comparar a viabilidade financeira do plano, mediante análise de projeção de fluxo de caixa, para saber se o plano proposto é exequível e o quanto os credores receberão se aprovarem o plano. Como contraponto, os credores compararão essa alternativa com a informação constante no laudo de avaliação dos bens e ativos do devedor, para saber o quanto receberiam em caso de rejeição ao plano e convolação da recuperação judicial em falência.

De fato, torna-se inócua a convocação de Assembleia Geral de Credores para deliberar sobre o plano de recuperação que sequer cumpra suas condições de admissibilidade. Ausente qualquer dos elementos dispostos no art. 53, deve ser declarada a nulidade de todo o plano, já que não ostenta as condições mínimas para ser submetido à deliberação dos credores. 
Por conseguinte, diferentemente dos preceitos intrínsecos de validade e eficácia do plano de recuperação judicial, o exame judicial dos quesitos arrolados no art. 53 deve ser realizado incontinenti ao recebimento do plano de recuperação judicial pelo juiz, para que sejam imediatamente constatadas e dirimidas irregularidades dessa natureza ${ }^{16}$.

A interpretação, ademais, é benéfica ao instituto. Ainda que o juízo entenda pela prorrogação do prazo e apresentação de um novo plano de recuperação judicial, busca-se evitar a convocação de assembleia (e todo o custo a ela inerente) para deliberação de um documento manifestamente inadmissível e inapropriado.

Nessa fase, o juízo será tão somente de admissibilidade, ou seja, restringir-se-á a constatar a presença dos requisitos elencados no artigo 53. Não se pretende a averiguação de conteúdo das cláusulas do plano ou, muito menos, de sua concreta viabilidade, função que é inicialmente reservada aos credores, e sucessivamente ao juízo antes da concessão da recuperação.

Cabe destacar que a apresentação do plano em juízo admite três possíveis desfechos. Primeiramente, se o plano for apresentado simultaneamente ao pedido de recuperação judicial, caberá ao juiz quando do deferimento do processamento da recuperação apreciar também o plano no âmbito das nulidades acima apontadas. Estando em termos e sendo admitido o documento, será determinada a publicação do Aviso aos Credores. Uma vez constatada qualquer irregularidade, será conferido ao devedor o prazo ordinário de 60 dias para apresentação

16 Adotando o mesmo entendimento, cf. RIO GRANDE DO SUL. Tribunal de Justiça, Quinta Câmara Cível. Agravo de Instrumento n. 0091278-87.2014.8.21.7000. Rel. Des. Isabel Dias Almeida, j. 30/04/2014, no qual a ausência de apresentação do laudo econômico-financeiro foi imediatamente constatada pelo Juízo que, diante da improrrogabilidade do prazo de sua apresentação, decretou a falência da devedora: "A apresentação do laudo econômico-financeiro no processo de recuperação judicial decorre de exigência legal, porquanto visa demonstrar a viabilidade da empresa, apesar das dificuldades apresentadas. [...] Certo é que o prazo para a apresentação do Plano de recuperação judicial, com o atendimento de todos os seus requisitos, é de sessenta dias, contados da publicação que deferiu o seu processamento. Na hipótese em comento, não houve a observância da determinação legal, sendo descabido o pedido de prorrogação de prazo". 
de um novo plano ou documentos que o complementam, sob pena de decretação de falência.

Outro desfecho será se o devedor apresentar o plano antes da consumação do prazo peremptório e o juiz determinar que a nulidade seja sanada. Nesse caso, o devedor gozará do período restante para apresentação de um novo plano de recuperação judicial, até que se esgote o prazo. A apresentação do plano no período de 60 dias não tem como efeito a preclusão consumativa do ato, tendo em vista que o plano poderá ser posteriormente alterado, conforme indica o art. $56, \S 3^{\circ}$ da LFRE $^{17}$. Finalmente, se apresentado no último dia do prazo de 60 dias, a declaração de nulidade do plano de recuperação judicial implicará, em regra, na decretação de falência do devedor, uma vez que a não lhe restará prazo suplementar para repetição tempestiva do ato.

\section{A decisão de concessão da recuperação e o controle judicial sobre o plano}

ALFRE criou um procedimento especial de votação para formação do contrato sui generis a ser celebrado entre devedor e credores no processo de recuperação judicial. Cercado de outras características e requisitos extrínsecos àqueles dos negócios jurídicos ordinários, o plano de recuperação judicial, por suas peculiaridades, reveste-se de outros pressupostos de validade além daqueles previstos no art. 104 do Código Civil, a merecer estrita observância.

Nesse aspecto, depreende-se que a soberania conferida à Assembleia Geral de Credores não é absoluta, pois, visando garantir o cumprimento da lei, o plano está submetido ao exame judicial de

17 Nesse sentido: MINAS GERAIS. Tribunal de Justiça, Oitava Câmara Cível. Agravo de Instrumento n. 1.0079.10.017400-6/004. Rel. Des. Teresa Cristina da Cunha Peixoto, j. 10/11/2011, no qual foi destacado que: "Além disso, o próprio art. 56, $\S 3^{\circ}$ da Lei 11.101/2005 mencionado pelos credores irresignados estabelece a possibilidade de que o plano possa sofrer alterações na assembleiageral, desde que haja expressa concordância do devedor e em termos que não impliquem a diminuição dos direitos exclusivamente dos credores ausentes, o que se amolda no caso em tela". 
legalidade ${ }^{18}$. Parece claro que, como qualquer negócio jurídico, não basta o consenso (ou a aprovação da maioria) para que o plano de recuperação judicial seja válido e eficaz entre as partes, devendo incorporar os requisitos legais destinados a lhe qualificar como negócio jurídico perfeito.

Nessa lógica, e revelando-se o viés processual da recuperação judicial, ao juiz foi atribuído papel chancelador da decisão assemblear, de modo a submeter o plano de recuperação - e também a própria assembleia geral - ao controle jurisdicional. A esse respeito, Paulo Fernando Campos Salles de Toledo (2013, p. 307) pontua:

É certo que a Lei dispõe que o juiz 'decretará a falência do devedor' se o plano tiver sido rejeitado, ou 'concederá a recuperação judicial' quando não tiver sofrido objeção ou tiver sido aprovado pela assembleia geral. Não quer isto dizer, no entanto, que o juiz deverá sempre, em qualquer caso, chancelar automaticamente a manifestação de vontade coletiva dos credores. O pronunciamento judicial terá forçosamente que aplicar a lei ao caso concreto, e para isso deverá levar em conta o preenchimento ou não dos requisitos legais.

Assim também já se posicionou, por mais de uma vez, o Superior Tribunal de Justiça, ao destacar que "a assembleia de credores é soberana em suas decisões quanto aos planos de recuperação judicial. Contudo, as deliberações desse plano estão sujeitas aos requisitos de

18 É possível extrair de inúmeros dispositivos da LFRE, que impõem proibições ou exigências ao devedor na elaboração do plano (ou na fase de sua execução) a necessidade de exame de legalidade, tais como: afastar a variação cambial sem o consentimento expresso do credor (art. $50, \S 2^{\circ}$ ); suprimir ou substituir a garantia real sem o consentimento do credor (art. $50, \S 1^{\circ}$ ); estender os efeitos da recuperação aos coobrigados solventes nas obrigações que assumir (violação ao art. $49, \S 1^{\circ}$ ) ou aos credores incluídos no art. 49 , $\S \S 3^{\mathrm{a}}$ e $4^{\mathrm{a}}$; estabelecer prazos para o pagamento dos créditos trabalhistas em desacordo com o art. 54; prever, como meio de recuperação, a cisão, incorporação, fusão ou transformação da sociedade empresária, constituição de subsidiária integral, ou cessão de cotas ou ações, sem respeitar os direitos dos sócios previstos na legislação (art. 50, II); prever a redução salarial, compensação de horários e redução da jornada, sem acordo ou convenção coletiva prévios. (art. 50, VIII); incluir cláusulas que impliquem tratamento diferenciado entre os credores da classe que o houver rejeitado, na situação prevista no art. $58, \S 1^{\circ}$ (aprovação do plano por metade ou maioria das classes votantes). Ademais, se o devedor optar pelo plano especial para ME e EPP, seu conteúdo é limitado aos incisos do art. 71. 
validade dos atos jurídicos em geral, requisitos esses que estão sujeitos a controle judicial"19; e "é certo que se submete ao controle jurisdicional a análise do preenchimento das condições prévias à concessão da recuperação e exigências legais relativas à elaboração e à aprovação do plano" (cf. Lei n 11.101/2005, art. 58). Por fim, destaca-se o enunciado n 44 aprovado na I Jornada de Direito Comercial: "A homologação de plano de recuperação judicial aprovado pelos credores está sujeita ao controle judicial de legalidade.".

Embora o controle judicial de legalidade seja consectário lógico da exegese dos princípios de direito e esteja manifestamente presente na LFRE, maiores embates afloram para definir o grau de incursão do juiz, constitucionalmente munido do poder jurisdicional, para circunscrever o exercício da autonomia da vontade pelas partes à luz dos híbridos direitos e interesses tutelados na LFRE.

A rigor, segundo a dicção do art. 58 da LFRE, cumpridas as exigências da lei, o juiz concederá a recuperação judicial ao plano de recuperação que não foi alvo de objeções ou aprovado na forma do art. 55. Ao que transparece, não lhe é conferida discricionariedade para análise do conteúdo do plano ou da manifestação de vontade dos credores, limitando-se a verificar o cumprimento das exigências formais de desenvolvimento da Assembleia Geral de Credores, restando vinculado ao seu resultado ${ }^{20}$ (MOREIRA, 2005, p. 253-254).

Por outro lado, há autores que defendem maior autonomia ao juiz, cabendo-lhe ponderar a deliberação assemblear frente aos princípios da LFRE - especialmente o da preservação da empresa - para analisar,

19 BRASIL. Superior Tribunal de Justiça. Recurso Especial n 1314209. Rel. Min. Nancy Andrighi, j. 22.05.2012.

20 MINAS GERAIS. Tribunal de Justiça. Quinta Câmara Cível. Agravo de Instrumento n. 1.0707.12.028102-7/004. Rel. Des. Fernando Caldeira Brant, j. 11/07/2014, destacando-se o seguinte trecho do acórdão: "Ora, cabe ao judiciário fazer uma análise objetiva quanto ao preenchimento das condições prévias à concessão da recuperação judicial, bem como aos requisitos formais impostos para que ocorra a aprovação de um plano, os quais, no caso concreto, foram devidamente preenchidos". 
formal e materialmente, o plano de recuperação do devedor (LOBO, 2005, p. 152-153; BEZERRA FILHO, 2009, p. 155).

Por fim, destaca-se o entendimento defendido por Leandro Santos de Aragão (2006, p. 304) e Ricardo Negrão (2010, p. 136), pelo qual é conferida a mais ampla autonomia do juiz para, inclusive, decidir contrariamente à Assembleia Geral de Credores quando verificado que um plano, embora rejeitado, é viável ${ }^{21}$.

Contrariando o dualismo presente nas ideologias acima expostas, apropriadamente se posiciona Eduardo Secchi Munhoz (2001), para quem a LFRE não deve ser observada à luz da falsa oposição entre a autonomia privada versus discricionariedade judicial, mas sob uma perspectiva de sinergia entre os agentes envolvidos no procedimento para atingir seus princípios e propósitos da Lei. Em suas palavras:

A verificação no caso concreto, portanto, da viabilidade da recuperação do devedor e do atendimento aos objetivos alinhados pelo art. 47 da Lei 11.101/2005 não cabe exclusivamente ao juiz, mas deverá resultar do processo de negociação entre devedor e credores estritamente regulado pela Lei (structured bargaining). A lei estrutura um processo de negociação entre devedor e credores que busca implementar um modelo de comportamento cooperativo, de convergência de interesses, em lugar de um comportamento individualista. Confia-se que desse processo de negociação estruturada (regulada pela lei) possa resultar a solução consentânea com o interesse público na preservação da empresa viável e na liquidação da empresa inviável.

Se ao juiz não deve caber o papel de simples homologação formal dos acordos entabulados entre devedor e coletividade

21 Nesse sentido, cf.: MINAS GERAIS. Tribunal de Justiça. $3^{\text {a }}$ Câmara Cível. Agravo de Instrumento n. 1.0702.07.347636-9/018. Rel. Des. Kildare Carvalho, j. 06/02/2014. Extrai-se do acórdão o seguinte fragmento: "No tocante a possibilidade de controle judicial das deliberações tomadas pela assembleia geral de credores, devo dizer que, de fato, o Estado-juiz, ao exercer o caráter jurisdicional do processo de recuperação judicial, detém o poder decisório. É dizer, o juiz não fica vinculado às deliberações tomadas na assembleia de credores.". 
de credores, também não the deve ser reconhecido o poder de substituir-se, de forma ampla e desvinculada das regras procedimentais da lei, à vontade manifestada pela assembleia geral de credores. A primeira solução poderia conduzir a resultados indesejados, porque pautados apenas pelos interesses egoísticos e individualistas dos credores, ao passo que a segunda desvirtuaria completamente o sistema, tornando irrelevante o papel da assembléia de credores. (MUNHOZ, 2001, p.184).

Seja pela concepção legalista, seja por aquela inclinada à maior autonomia jurisdicional, comuta-se do entendimento que apenas quando constatada pelo juiz a presença de requisitos legais de validade do plano, estabelecidos em Lei, é que a recuperação poderá ser concedida.

Mas quais seriam esses requisitos? A LFRE é lacunosa e discorre timidamente sobre a matéria, proporcionando ampla margem interpretativa aos doutrinadores e tribunais. Expressos ou implícitos, formais ou materiais, cogentes ou dispositivos e, nessa medida, suscetíveis ou não ao controle judicial, as exigências legais ao plano de recuperação judicial permanecem vagas. No momento de prolação da decisão de concessão da recuperação judicial ao devedor cujo plano de recuperação fora aprovado em Assembleia Geral de Credores, o juiz põese diante de arenoso terreno, consistente em auferir o cumprimento dos preceitos legais. Diante disso, merece cuidadosa análise os parâmetros desenvolvidos pela doutrina e empregados pelos tribunais brasileiros para conferir validade aos planos de recuperação judicial aprovados pelos credores.

3.1 A elaboração das cláusulas do plano de recuperação judicial e suas limitações: análise da jurisprudência

O plano de recuperação judicial contém, inevitavelmente, matérias de interesse público que, por sua natureza, são imperativas, ao lado de normas dispositivas que traduzem interesses eminentemente privados e flexíveis (REALE, 2002, p. 131-134). Para o exercício do controle judicial de legalidade, a diferenciação da natureza das normas tratadas no plano 
de recuperação demonstra-se como ponto de partida à constatação de eventual controle material de legalidade, bem como sua intensidade diante de normas cogentes ou dispositivas ${ }^{22}$. Um exame desmedido do julgador acerca de normas que admitem, ou não, flexibilização pode ferir a autonomia negocial conferida aos agentes envolvidos na recuperação judicial, atingindo em cheio o espírito da LFRE. A propósito, já se manifestou a Quarta Turma do Superior Tribunal de Justiça, em acórdão relatado pelo Min. Luís Felipe Salomão. Em suas palavras:

Se é verdade que a intervenção judicial no quadrante mercadológico de uma empresa em crise visa tutelar interesses públicos relacionados à sua função social e à manutenção da fonte produtiva e dos postos de trabalho, não é menos certo que a recuperação judicial, com aprovação do plano, desenvolve-se essencialmente por uma nova relação negocial estabelecida entre o devedor e os credores reunidos em assembleia.

\section{$[\ldots]$}

De fato, internamente às tratativas referentes à aprovação do plano de recuperação, muito embora de forma mitigada, aplica-se o princípio da liberdade contratual, decorrente da autonomia da vontade. São apenas episódicos - e pontuais, com motivos bem delineados - os aspectos previstos em lei em que é dado ao Estado intervir na avença levada a efeito entre devedor e credores ${ }^{23}$.

Portanto, embora a LFRE albergue preceitos nitidamente imperativos, outros decorrem de sua exegese e são defendidos pela doutrina e tribunais, razão pela qual se revela oportuna a construção jurisprudencial em torno da matéria, conforme passa-se a analisar.

\footnotetext{
22 A propósito, Miguel Reale (2002, p. 133) destaca que a imperatividade de uma norma jurídica também pode advir da doutrina e jurisprudência, pois é através das pesquisas e decisões judiciais que se extraem os limites de sua expressão verbal, segundo exigências fatuais e valorativas, para que correspondam às contingências sociais e econômicas.

23 BRASIL. Superior Tribunal de Justiça. Quarta Turma. Recurso Especial n. 1359311. Rel. Min Luís Felipe Salomão, j. 30/09/2014.
} 


\subsubsection{A extensão da novação operada pela homologação do plano de recuperação judicial aos garantidores e coobrigados}

Inicialmente, deve-se pontuar que a novação das obrigações operada pela concessão da recuperação judicial difere-se do tradicional instituto regido pelos arts. 360 a 367 do Código Civil, notadamente por seus particulares efeitos. Primeiro, porque a novação tratada no âmbito da LFRE possui uma condição resolutiva, qual seja, o regular cumprimento da nova obrigação, conforme disposto no art. $61, \S 2^{\circ}$ da $\mathrm{LFRE}^{24}$. Uma vez descumpridas as obrigações contidas no plano e decretada a falência do devedor, retorna-se às condições originalmente contratadas $^{25}$ (COELHO, 2013, p. 169). Segundo, pois a "novação recuperacional" não atrai a regra geral prevista no art. 366 do Código Civil de exoneração do fiador, porquanto a LFRE dispõe que os credores do devedor conservam seus direitos e privilégios em face dos coobrigados ${ }^{26}$. Via de regra, serão mantidas as garantias, sejam de natureza acessória ou autônoma, pessoal ou real. (LOBO, 2007, p. 136) ${ }^{27}$.

Não obstante, por se tratarem de direito disponível e caráter privado, as decisões em torno da matéria têm demonstrado a admissão da derrogação convencional dos efeitos da novação, excluídos os credores ausentes e que se abstiveram.

Assim se posicionou a Câmara Reservada à Falência e Recuperação, do Tribunal de Justiça do Estado de São Paulo, ao

24 "Art. 61, §2. Decretada a falência, os credores terão reconstituídos seus direitos e garantias nas condições originalmente contratadas, deduzidos os valores eventualmente pagos e ressalvados os atos validamente praticados no âmbito da recuperação judicial."

25 Assim também já se manifestou o Superior Tribunal de Justiça: BRASIL. Superior Tribunal de Justiça. Terceira Turma. Recurso Especial n. 1260301/DF. Rel. Min. Nancy Andrighi, j. 14/08/2012.

26 "Art. 49, §10 Os credores do devedor em recuperação judicial conservam seus direitos e privilégios contra os coobrigados, fiadores e obrigados de regresso".

27 O mesmo entendimento é compartilhado pelo Superior Tribunal de Justiça e diversos Tribunais Estaduais brasileiros: BRASIL, Superior Tribunal de Justiça, Segunda Seção. Conflito de Competência n. 112.620, rel. Min. Paulo de Tarso Sanseverino. j. 24/11/2010; SANTA CATARINA. Agravo de Instrumento n. 2013.001316-2. Rel. Guilherme Nunes Born, j. 19/09/2013; SÃO PAULO. Tribunal de Justiça. Câmara Reservada à Falência e Recuperação. Agravo de Instrumento $\mathrm{n}^{\circ}$ 0137526-29.2011.8.26.0000. Rel. Des. Elliot Akel, j. 13/12/11; RIO GRANDE DO SUL, Tribunal de Justiça, Décima Oitava Câmara Cível. Agravo de Instrumento n. 70041336363. Rel. Des. Pedro Celso Dal Pra, j. 31/03/2011; 
apreciar a seguinte cláusula disposta no plano de recuperação da sociedade empresária Accentum Manutenção e Serviços Ltda.:

M. Como parte integrante do Plano de Recuperação, os credores e a ACCENTUM reciprocamente se comprometem a não iniciar e/ou desistir de todas as ações e recursos judiciais referentes aos créditos objeto do Plano, inclusive no que se refere a avais, fianças e garantias oferecidas pela ACCENTUM, seu sócio, administradores e por terceiros;

N. A aprovação do Plano de recuperação judicial implicará na novação das obrigações contraídas perante todos os credores da recuperanda, alcançando, ainda, as obrigações solidárias dos sócios e demais garantidores, o que implicará também na extinção destas obrigações ${ }^{28}$.

Por entender tratar-se de direito disponível, as duas cláusulas foram declaradas ineficazes pela Câmara em face do credor que interpôs agravo de instrumento da decisão que concedeu a recuperação judicial sem ressalvar os efeitos dessas cláusulas.

Em solução divergente, a Primeira Câmara Reservada de Direito Empresarial do Tribunal de Justiça de São Paulo, ao apreciar semelhante cláusula contida no plano de recuperação de Comercial Ribeiro Pintão Importação e Exportação Ltda., determinou a absoluta ineficácia da extensão dos efeitos da novação, com fundamento na incompetência do Juízo falimentar para fazê-lo ${ }^{29}$.

Sobre a questão, entende-se que a melhor solução foi adotada no acórdão proferido pela Terceira Câmara Cível do Tribunal de Justiça da Bahia, também ao enfrentar cláusula extensiva dos efeitos da novação aos coobrigados, contida no plano de recuperação de Agropecuária

28 SÃO PAULO. Tribunal de Justiça. Câmara Reservada à Falência e Recuperação. Agravo de Instrumento n. 0282057-82.2009.8.26.0000. Rel. Des. Romeu Ricupero, j. 06/04/2010.

29 SÃO PAULO. Tribunal de Justiça, Primeira Câmara Reservada de Direito Empresarial. Agravo de Instrumento n. 2041474-29.2014.8.26.0000, rel. Des. Francisco Loureiro, j. 14/08/2014. No mesmo sentido: RIO GRANDE DO SUL. Tribunal de Justiça. Sexta Câmara Cível. Agravo de Instrumento n. 0234977-73.2013.8.21.7000. Rel. Des. Ney Wiedemann Neto, j. 24/10/2013. 
Arakatu Ltda. e Cotton Placas Ltda. ${ }^{30}$. Por compreender a natureza dispositiva da garantia, a cláusula foi declarada ineficaz perante todos os que não a ratificaram expressamente, compreendendo os credores ausentes à assembleia, os que votaram pela rejeição do plano ou, ainda, os que votaram pela sua aprovação, mas ressalvaram sua oposição quanto à referida cláusula. Tal entendimento demonstra-se mais adequado por preservar a autonomia da vontade das partes, diante de um privilégio de natureza estritamente patrimonial, sendo seguido por diversos outros órgãos julgadores ${ }^{31}$.

Questão reflexa à extensão dos efeitos da novação aos coobrigados é a suspensão da exigibilidade do crédito submetido aos efeitos do plano de recuperação judicial. Trata-se de matéria controversa nos tribunais.

A Nona Câmara Cível do Tribunal de Justiça do Estado do Rio de Janeiro analisou a questão ao se deparar com a seguinte cláusula, disposta no plano de Recuperação de Tecnosolo Engenharia S.A.:

Cláusula 3.5.: A aprovação do Plano de Recuperação acarretará, por força do disposto no art. 59 da Lei n. $11.101 / 2005$, a novação das dívidas sujeitas à recuperação, e também daquelas que, mesmo não sujeitas à recuperação, foram relacionadas e não contestadas pelos respectivos credores.

Desta forma, fica desde já estabelecida a suspensão da exigibilidade dos créditos junto aos avalistas, enquanto o Plano de recuperação judicial estiver sendo cumprido, e que somente serão liberadas as garantias quando houver a quitação nos termos previstos neste Plano de recuperação judicial (grifou-se).

30 BAHIA. Tribunal de Justiça. Terceira Câmara Cível. Agravo de Instrumento n. 001536332.2011.8.05.0000. Rel. Des. Lisbete Mª Almeida Cézar Santos, j. 13/11/2012.

31 Cf. SÃO PAULO. Tribunal de Justiça. Primeira Câmara Reservada de Direito Empresarial. Rel. Des. Manoel de Queiroz Pereira Calças, j. 31/07/2012. Afirmando-se "No que concerne à liberação de garantias reais e fidejussórias, tal cláusula só tem eficácia para os credores que votaram favoravelmente ao plano, consoante expressa ressalva constante da ata e na estrita observância do art. 50, $\S 1^{\circ}$, da LFR.”; e BAHIA. Tribunal de Justiça. Terceira Câmara Cível. Agravo de Instrumento n. 0015363-32.2011.8.05.0000. Des rel. Lisbete Ma Almeida Cézar Santos, j. 14/11/2012. 
Sob a relatoria do Des. José Roberto Portugal Compasso, o acórdão proferido pela Turma Julgadora declarou a ineficácia total da cláusula, por violar o $\S 1^{\circ}$, do art. $49^{32}$.

Diferentemente posicionou-se a Câmara Especial Regional de Chapecó, do Tribunal de Justiça de Santa Catarina. A cláusula, disposta no plano de recuperação judicial de Embracol Empresa Brasileira de Construção Civil Ltda., determinava a suspensão da exigibilidade dos créditos submetidos ao plano, inclusive aqueles garantidos por terceiros e, no caso de cumprimento de todas as obrigações nele dispostas, a quitação integral em face dos garantidores. O trecho do acórdão, sob relatoria do Des. Eduardo Mattos Gallo Junior, merece transcrição pela sutileza com que trata o tema:

Em que pese o entendimento majoritário, tanto da doutrina, quanto da jurisprudência, ser no sentido de que a homologação do plano de recuperação judicial não impede a continuidade dos feitos executivos em face dos terceiros garantidores, em decorrência de expressa previsão legal artigo $49, \S 1 .^{\circ}$, da Lei de Regência -, tem-se que referido dispositivo legal merece melhor exegese. Isso porque, não há qualquer motivo plausível para se determinar o prosseguimento das execuções em face dos terceiros, posto que, estando sendo cumprido o plano homologado, inexiste inadimplemento substancial apto a ensejar as demandas executivas. Em resumo, não há a caracterização da mora, fato este que afasta, por decorrência lógica, a possibilidade de se executar até mesmo os terceiros garantidores. Além do mais, a não suspensão em face dos terceiros fere a lógica da segurança jurídica, considerando-se que o norte do beneplácito à devedora vem a ser a renegociação do pagamento de suas obrigações o que, inevitavelmente, se deferido, afasta sua mora, esta que é a condição sine qua nom à protocolização das expropriatórias. Se não bastasse, em que pese não se discutir a autonomia do credor frente

32 RIO DE JANEIRO. Tribunal de Justiça. Nona Câmara Cível. Agravo de Instrumento n. 004725765.2013.8.19.0000. Rel. Des. José Roberto Portugal Compasso, j. 03/12/2013. 
aos terceiros garantes, se mostra desarrazoado, muito menos justo, que o terceiro seja obrigado a satisfazer a obrigação, na situação em que não há a certeza de que não possa o devedor assim proceder, mesmo que em uma situação diversa da originariamente pactuada, a qual, salienta-se, possui indiscutível carga de legalidade. Outrossim, eventual manutenção da cobrança perante os garantes, poderia ensejar em novas habilitações no plano de recuperação judicial - caso dos mesmos adimplirem o débito -, ocasionando maiores transtornos no principal objetivo pelo qual o acordo restou homologado, qual seja, recuperar a integridade econômica da empresa, a fim de manter, não apenas a estabilidade de seus proprietários com o adimplemento dos débitos existentes, resguardando, sem sombra de dúvidas, o direito dos credores -, mas, principalmente, dos inúmeros colaboradores que laboram e dependem de seu salário mensal para sobreviver ${ }^{33}$.

No caso em tela, concluiu-se que os direitos e privilégios dos coobrigados e fiadores, apesar não serem suprimidos, deveriam permanecer suspensos enquanto não for caracterizado o inadimplemento substancial da dívida garantida pelo devedor em recuperação, sob pena de tornar-se inócua a disposição do art. 49, $\S 1^{\circ}$, da LFRE. Uma vez que o cumprimento do plano de recuperação judicial significa o adimplemento da obrigação, não seria possível exigir o crédito antecipadamente em face de coobrigados e fiadores ou o prosseguimento das ações em face deles.

Como bem ressaltado no acórdão, a matéria, de fato, não é pacífica. A Segunda Câmara Reservada de Direito Empresarial do Tribunal de Justiça de São Paulo já opinou em sentido diverso, ao apreciar cláusula análoga, contida no plano de recuperação judicial de Wirex Cable S/A, assim redigida: 
Enquanto estiverem sendo cumpridas as obrigações previstas no presente plano de recuperação judicial, deverão ser suspensas todas as ações e execuções movidas contra as recuperandas, acionistas, quotistas, fiadores, avalistas e coobrigados decorrentes das dívidas sujeitas aos efeitos da Recuperação Judicial.

Por entender pela violação ao art. $49, \S^{\circ}$, da LFRE, o órgão julgador declarou a cláusula ineficaz em face do credor agravante ${ }^{34}$.

Com efeito, as cláusulas em comento merecem análise segregada. Ao reunir fiadores e avalistas, elas acabam por misturar institutos distintos. A suspensão das ações opostas em face de fiadores, quando não caracterizado o inadimplemento do devedor, demonstra-se adequada tendo em vista que o instituto, por sua natureza, reveste-se do benefício de ordem, disposto no art. 827 do Código Civil, o que não é afastado pela LFRE, salvo se o fiador a ele renunciar expressamente ou se obrigar como garante solidário (art. 828 do Código Civil). Entretanto, o mesmo não se aplica ao aval. A garantia, própria do direito cambiário, constitui obrigação autônoma do avalista perante o credor (art. 899, $\$ 2^{\circ}$, do Código Civil). Portanto, a sujeição da dívida aos efeitos da recuperação judicial do avalizado não atingirá a obrigação existente entre o avalista e o credor.

\subsubsection{Abuso na previsão de prazos e condições especiais de pagamento, notadamente deságio, das obrigações vencidas e vincendas}

A concessão de prazos e condições especiais de pagamento é um dos meios de recuperação expressamente previstos na LFRE, conforme se extrai do seu art. $50, \mathrm{I}^{35}$.

34 SÃO PAULO. Tribunal de Justiça. Segunda Câmara Reservada de Direito Empresarial. Agravo de Instrumento n. 0036314-91.2013.8.26.0000. Rel. Des. Tasso Duarte de Melo, j. 19/08/2013.

35 RIO DE JANEIRO. Tribunal de Justiça, Décima Oitava Câmara Cível. Agravo de Instrumento 0051870-65.2012.8.19.0000. Rel. Des. Jorge Luiz Habib, j. 04/12/2012, assim fundamentado: "A decisão da Assembleia Geral de Credores é soberana, não sendo concebível que se venha fazer prevalecer interesse de outrem sobre o dos próprios credores, que decidiram conforme a citada cláusula "5.4.1" ao aprovar o plano de recuperação." 
Como se nota, diferentemente do Decreto-Lei $n^{\circ} 7.661 / 1945$, que estabelecia, na concordata preventiva, o pagamento integral dos credores quirografários em até 24 meses, o legislador da LFRE não fixou limites, prazos ou formas de pagamento, revelando-se o caráter negocial do regime de recuperação judicial, pelo qual a Assembleia Geral de Credores é concebida como órgão destinado a propiciar a defesa dos interesses dos credores e a deliberação do conteúdo do plano pelos credores, fomentando-se a negociação com o devedor.

Nessa perspectiva, diversos são os casos enfrentados pelos tribunais pátrios nos quais restou reconhecida a soberania do órgão para tutelar o interesse dos credores e, inclusive, submeter seus resultados a todos os credores sujeitos aos efeitos do plano, salvo quanto às cláusulas que admitem derrogação particular ${ }^{36}$. A questão, contudo, não é unânime e existem julgados mais restritivos e outros extremamente liberais.

No Tribunal de Justiça do Estado de São Paulo, destaca-se a aparente mudança de entendimento na Primeira Câmara Reservada de Direito Empresarial. Em 2013, ao apreciar o plano de recuperação judicial proposto por Oswaldo Baldin Administração e Participações S/A, em recuperação judicial, e outros, a Câmara declarou nula a cláusula que previa o deságio de $50 \%$ do valor nominal dos créditos, com fundamento em suposta abusividade. Foi determinada a apresentação de uma nova proposta, embora o plano tivesse sido aprovado em assembleia de credores ${ }^{37}$. Não obstante, em 2014, em acórdão relatado pelo Des. Fernando Antonio Maia da Cunha, pelo qual era proposto idêntico deságio de $50 \%$ sobre todos os créditos sujeitos ao plano, a mesma Câmara manifestou entendimento de que

36 RIO DE JANEIRO. Tribunal de Justiça, Décima Oitava Câmara Cível. Agravo de Instrumento 0051870-65.2012.8.19.0000. Rel. Des. Jorge Luiz Habib, j. 04/12/2012, assim fundamentado: "A decisão da Assembleia Geral de Credores é soberana, não sendo concebível que se venha fazer prevalecer interesse de outrem sobre o dos próprios credores, que decidiram conforme a citada cláusula "5.4.1" ao aprovar o plano de recuperação."

37 SÃO PAULO. Tribunal de Justiça. Primeira Câmara Reservada de Direito Empresarial. Agravo de Instrumento n. 0076455-55.2013.8.26.0000. Rel. Des. Enio Zuliani, j. 29/08/2013. 
em princípio, não deve o Poder Judiciário entrar nesse mérito para afirmar que o percentual do deságio aplicado é abusivo ou indiciário da inviabilidade da empresa. Conquanto elevado o percentual, fato é que a Assembleia Geral de Credores o reputou melhor aos interesses dos titulares dos créditos e o aprovou. ${ }^{38}$

A Segunda Câmara de Direito Empresarial do mesmo tribunal parece não ter a mesma concepção. Em acórdão de relatoria do Des. Ricardo Negrão, a Câmara entendeu que o deságio de $50 \%$ sobre a dívida submetida ao plano de recuperação judicial, embora aprovado em assembleia de credores, configura pagamento vil, sobretudo se comparado às porcentagens mínimas historicamente previstas no regime de concordata preventiva ${ }^{39}$.

Em outros tribunais pátrios, a matéria parece estar mais sedimentada para defender a autonomia dos credores em deliberar os critérios de pagamento de seus créditos. Assim, por exemplo, manifestou-se a Quinta Câmara Cível do Tribunal de Justiça de Minas Gerais, reconhecendo que, apesar da proposta de $80 \%$ de deságio sobre os créditos submetidos ao plano de recuperação judicial, não cabe ao Poder Judiciário interferir no mérito da deliberação, especialmente diante de sua aprovação em Assembleia Geral de Credores ${ }^{40}$.

Questão indiretamente referente ao deságio e, consequentemente, de aspecto patrimonial, a incidência de juros e correção monetária sobre o crédito submetido aos efeitos do plano de recuperação judicial também não está alheia a entendimentos contrários. De acordo com a Primeira

38 SÃO PAULO. Tribunal de Justiça, Primeira Câmara Reservada de Direito Empresarial. Agravo de Instrumento n. 2110784-25.2014.8.26.0000. Rel. Des. Fernando Antonio Maia da Cunha, j. $11 / 09 / 2014$.

39 SÃO PAULO. Tribunal de Justiça. Segunda Câmara Reservada de Direito Empresarial. Agravo de Instrumento n. 0055083-50.2013.8.26.0000. Rel. Ricardo Negrão, j. 25/07/2014. Com o mesmo entendimento: SÃO PAULO. Tribunal de Justiça. Segunda Câmara Reservada de Direito Empresarial. Agravo de Instrumento n. 0109227-71.2013.8.26.0000. Rel. Des. Lígia A. Bisogni, j. 16/07/2014.

40 MINAS GERAIS. Tribunal de Justiça. Quinta Câmara Cível. Agravo de Instrumento n. 1.0024.12.283623-2/027. Rel. Des. Fernando Caldeira Brant, j. 25/09/2014. 
Câmara Reservada de Direito Empresarial do Tribunal de Justiça do Estado de São Paulo, a ausência de previsão de incidência de correção monetária enseja a decretação de nulidade do plano de recuperação judicial, tendo em vista que o crédito suportaria um duplo deságio, em razão da natural - e imprevisível - taxa de inflação, notadamente quando o prazo de pagamento for extenso ${ }^{41}$. Contudo, o entendimento não se repete, inclusive, dentro do mesmo tribunal.

A Segunda Câmara Reservada de Direito Empresarial manifestou entendimento contrário e assaz liberal, ao decidir que a incidência de correção monetária e juros é de caráter patrimonial individual e, portanto, disponível aos credores, inclusive para deliberar a taxa de atualização que julgarem apropriada. O acórdão, de relatoria do Des. Ramon Mateo Júnior, assevera o seguinte:

É cediço que a correção monetária não representa lucro ou acréscimo patrimonial, destinando-se unicamente à atualização do valor monetário do crédito. Tal circunstância, contudo, não lhe subtrai o caráter patrimonial, de modo que, anuindo os interessados com a adoção de determinado índice, no caso a Taxa Selic, deve prevalecer a decisão da Assembleia Geral de Credores, que detém soberania. ${ }^{42}$

Tal posicionamento foi compartilhado pela Nona Câmara Cível do Tribunal de Justiça do Estado do Rio de Janeiro, em acórdão de relatoria do Des. José Roberto Portugal Compasso, para quem "são direitos disponíveis sem implicações de ordem pública"43. Portanto, não há ilegalidade se o plano de recuperação estabelecer a não incidência de correção monetária para os credores quirografários que optarem por receber a dívida em 15 anos, após o período de carência.

41 SÃO PAULO. Tribunal de Justiça. Primeira Câmara Reservada de Direito Empresarial. Agravo de Instrumento n. 0020538-51.2013.8.26.0000. Rel. Des. Francisco Loureiro, j. 04/07/2013.

42 SÃO PAULO. Tribunal de Justiça. Segunda Câmara Reservada de Direito Empresarial. Agravo de Instrumento n. 2071805-91.2014.8.26.0000. Rel. Des. Ramon Mateo Júnior, j. 17/11/2014.

43 RIO DE JANEIRO. Tribunal de Justiça. Nona Câmara Cível. Agravo de Instrumento n. 0047152 88.2013.8.19.0000. Rel. Des. José Roberto Portugal Compasso, j. 26/11/2013. 


\section{CONCLUSÃO}

A ampla autonomia conferida ao devedor para projetar os meios de recuperação os quais julgar apropriados à sua reestruturação revela indispensável flexibilidade ao processo, criando, através da assembleia geral, o cenário ideal de negociação entre devedor e credores sobre o melhor caminho a ser trilhado para o futuro de sua empresa.

A busca pela convergência desses interesses, descritos pelo legislador no artigo 47 da LFRE, configura o verdadeiro desafio a ser enfrentado por todos os órgãos envolvidos diretamente na recuperação judicial, e sustenta a reflexão em torno do papel do juiz como garantidor dessa harmonização, onde o resguardo da autonomia negocial das partes é essencial.

A primeira conclusão é que se revela apropriada a submissão do plano de recuperação judicial ao controle judicial, de modo a assegurar o imperioso cumprimento dos pressupostos de legalidade destinados a proporcionar substrato ao devedor e credores para deliberação sobre o direito tutelado no plano de recuperação. Não obstante, a intervenção desmoderada aos interesses de natureza eminentemente individual e patrimonial pode configurar excessiva intervenção estatal no procedimento que, sem dúvidas, tem repercussões econômicas.

Desta forma, deve-se observar que o plano de recuperação judicial é de natureza eminentemente contratual, e, como tal, reveste-se da autonomia da vontade das partes a ele vinculadas, razão pela qual não deve ser descaracterizada a soberania - ainda que mitigada - do devedor e credores para dispor sobre o seu conteúdo.

Portanto, no exercício do controle de legalidade, deve o juiz analisar o conteúdo do plano de recuperação judicial para verificar eventuais transgressões a normas de direitos indisponíveis, sem deixarse levar sobre a razoabilidade da negociação que se aprecia, sob pena de descaracterizar o instituto. 


\section{REFERÊNCIAS}

AGUIAR, Márcio Luiz. Empresa: recuperação e liquidação na nova lei de falência. Florianópolis: Habitus, 2006.

ARAGÃO, Leandro Santos de; CASTRO, Rodrigo R. Monteiro de (Coord.). Direito societário e a nova lei de falências e recuperação de empresas. São Paulo: Quartier Latin, 2006.

AYOUB, Luiz Roberto; CAVALLI, Cássio. A construção jurisprudencial da recuperação judicial de empresas. Rio de Janeiro: Forense, 2013.

BEZERRA FILHO, Manoel Justino. Lei de recuperação de empresas e falências: Lei n ${ }^{0}$ 11.101/2005 comentada artigo por artigo. 6. ed. rev. e atual. São Paulo: Revista dos Tribunais, 2009.

CAMPINHO, Sérgio. Falência e recuperação de empresa: o novo regime da insolvência empresarial. 6. ed. Rio de Janeiro: Renovar, 2012.

COELHO, Fábio Ulhôa. Curso de direito comercial. 14. ed. São Paulo: Saraiva, 2013. v. 3.

MUNHOZ, Eduardo Secchi. Anotações sobre os limites do poder jurisdicional na apreciação do plano de recuperação judicial. Revista de Direito Bancário e Mercado de Capitais, Porto Alegre v. 36, p. 184, abr. 2007.

NEGRÃO, Ricardo. Manual de direito comercial \& de empresa. 8. ed. Saraiva: São Paulo, 2010.

PACHECO, José da Silva. Processo de recuperação judicial, extrajudicial e falência: em conformidade com a lei n. 11.101/05 e a alteração da lei n. 11.127/05. Rio de Janeiro: Forense, 2007.

PAIVA, Luiz Fernando Valente. Direito falimentar e a nova lei de falências e recuperação de empresas. São Paulo: Quartier Latin, 2005.

REALE, Miguel. Lições preliminares de direito. 27. ed. São Paulo: Saraiva, 2002. 
TOLEDO, Paulo Fernando Campos Salles de; ABRÃO, Carlos Henrique (Coord.). Comentários à lei de recuperação de empresas e falência. 2. ed. São Paulo: Saraiva, 2007.

TOLEDO, Paulo Fernando Campos Salles de. O plano de recuperação judicial e o controle judicial da legalidade. Revista de Direito Bancário e do Mercado de Capitais, São Paulo, v. 60, p. 307, abr. 2013.

TOMAZETTE, Marlon. Curso de direito empresarial: falência e recuperação judicial de empresa. v. 3. São Paulo: Atlas, 2014.

UBALDO, Edson. Recuperação judicial e extrajudicial de empresas: comentários aos artigos específicos da Lei n. 11.101, de 9-2-2005. Florianópolis: Conceito, 2008.

Recebido em: 20/03/2015

Aprovado em: 19/06/2015 